\title{
The Public and Private Papers of Judge William F. Riley
}

R O B ERT A. CARP

In 1958 the widow of the late Federal District Judge William Francis Riley presented her husband's political and judicial papers to the Special Collections Department of The University of Iowa Library. These papers, nearly seven thousand in number, cover a twenty-four year period: from 1932, when William Riley first entered the political arena, until his death in 1956, after he had served for six years as a federal judge for the Southern District of Iowa. The Riley collection is composed primarily of correspondence between the Judge and leading public, political, and judicial figures of the time, not only in Iowa but throughout the United States.

Judge Riley's papers provide information and insight into three separate phases of his public career, each of which is of particular interest to students of the American political process. The first phase dates from 1932 to 1941, when William Riley was a political activist and adviser to a number of prominent Democratic officeholders. The second spans the years 1941 through 1950 when Riley was a leader in the Iowa State Bar Association and in numerous religious and civic activities, many of which exerted an important influence on the Iowa political process. The final phase occurred from 1951 through 1956, when William Riley served with distinction as a federal district judge.

\section{RILEY THE POLITICAL ACTIVIST}

There is no indication that William Riley had much interest in or contact with the world of politics prior to 1932. After attending The University of Iowa between 1903 and 1907, he immediately entered the College of Law in Iowa City from which he was graduated two years later. The following twenty-three years were filled with the problems and activities of rearing six children and of establishing himself with a reputable Des Moines law firm. However, it was not 
simply the demands of his family and of his professional career which kept William Riley from being a political activist prior to 1932: the hard political facts of life in the state of Iowa were most assuredly an additional factor in this regard. Riley was an urban, Catholic, "wet" Democrat in a state which was rural, Protestant, "dry," and overwhelmingly Republican. Before the winds of political change began to blow in Iowa during the early 1930s, Riley must have been fully aware that his affinity for the Democratic Party was an insurmountable handicap in any effort to advance his public or political ambitions.

However, beginning with the ever-worsening farm depression of the late 1920s and the stock market collapse of 1929, a dramatic shift toward the Democratic Party began in Iowa and in the nation at large. In addition, the several months prior to the 1932 election saw an enormous influx into the political arena of persons who had previously been politically inactive. Many of these new political activists were relatively young individuals of a liberal-reformist persuasion who saw in the Democratic Party America's only hope in extricating itself from the economic and social dislocations caused by the Great Depression. Among these new reform-minded political activists was a successful Des Moines attorney-William Francis Riley.

The catalyst which projected Riley into the 1932 campaign was his close personal relationship with Clyde Herring, a Des Moines auto dealer who was seeking the Democratic gubernatorial nomination. Riley worked actively for Herring in the weeks preceding the Democratic primary, and wrote scores of letters to influential Iowa Democrats urging their support for Clyde Herring. Herring handily won the Democratic nomination, and after a spirited campaign was elected Governor of Iowa. Soon after his election, Governor Herring turned to his trusted friend and supporter, Will Riley, for help and counsel in managing the affairs of state in their native Iowa. In an official capacity, Riley was appointed chairman of the Iowa Legislative Interim Committee during the first two years of Herring's gubernatorial career, and in 1933 Herring appointed Riley to represent Iowa in Washington, D.C., for the purpose of helping to obtain funds from the Reconstruction Finance Corporation for use in Iowa.

Despite his official activities as the Governor's representative, Riley's major impact upon Iowa politics during the 1930s derived from his unofficial association with the Iowa Governor. Not only did Riley write many of Herring's major addresses and provide the Governor with shrewd political advice, but it appears that Riley aided Herring in the distribution of state patronage positions. As one of Riley's admirers put it in a letter to an old friend, "Whenever Clyde Herring shows wisdom, the thought comes from Will Riley." 
In addition to revealing his close association with Governor Herring, the Riley papers indicate that William Riley was also a close friend and adviser to two of Iowa's Democratic senators of the 1930s. They were Senator Louis Murphy, who served between 1932 and 1936 (when he was killed in an automobile accident), and Senator Guy Gillette, who was elected in 1936 to fill Murphy's unexpired term and who was subsequently reelected two years later. Nearly all of the Riley-Murphy interaction dealt with matters of federal patronage appointments which Murphy was in a position to bestow as Iowa's only Democratic senator. Most of the communication between William Riley and Guy Gillette consisted of Riley providing the Senator with shrewd political advice. For example, when it became clear that Gillette's only hope for reelection in 1938 lay in winning massive Republican defections, Riley urged upon the Senator this sage political tactic:
A Republican newspaper man suggested to me only last night that you do not attack Republicans in the mass, but that if you are going to criticize them you do it by referring to the "Spangler crowd" so that those Republicans who may have turned to you on account of your court stand [i.e., Gillette's stand against the Roosevelt Court-packing proposal] will not be offended. 1

There is evidence in the collection of papers that Riley also provided the Senator with valuable advice on how Gillette should vote and conduct himself in the Senate so as to maintain the continuing support of the Iowa electorate.

In sum, the Riley papers of the 1930s provide an extremely fruitful source of data for any student of government or politics who has a special interest in the events, crises, and behind-the-scenes maneuvers of this extremely colorful political era.

\section{RILEY THE LEADER IN IOWA PUBLIC AFFAIRS}

After the elections of 1940 the nature of William Riley's association with the Democratic Party underwent a major change: the great enthusiasm and active participation which characterized Riley's association with the Democratic Party during the 1930s gave way to a state of cynicism and inactivity after 1940. This was owing to at least three factors.

First, Riley became increasingly disillusioned with his party's basic principles and programs, which he felt were far too radical, leading in the direction of what he termed "an un-American welfare state." Second, the Republican resurgence in Iowa, which had begun in 1938 and made itself fully felt in 1940, denied Riley the privileged access to the

1 William F. Riley to Guy M. Gillette, October 18, 1938. 
sources of power and influence in the state which he had enjoyed during the 1930s. Finally, during the 1940s the weakened Democratic Party in Iowa became increasingly aligned with, and dependent upon, the national party leadership, which was quite liberal in orientation. This, in turn, meant that the conservatively-oriented Riley wing of the Iowa Democratic Party was no longer in a position to distribute patronage nor to determine the general direction and orientation of the party.

As William Riley and the Democratic Party began to take separate paths after 1940, Riley turned his interest and energies toward Iowa civic affairs, religious pursuits, and bar association activities. The Riley papers contain ample material on all of the following endeavors undertaken by William Riley during the 1940s.

In civic affairs, he served as special assistant to the U.S. Attorney General as hearing officer for conscientious objectors for the Southern District of Iowa between 1942 and 1946; he was an active member of the Navy League for Iowa during the war and was League President in 1946; in 1943 Riley was elected president of the Des Moines Adult Education Council, and he was for several years in charge of securing speakers for the Council's Public Forums; all during the 1940s Riley was on the board and an active supporter of the Des Moines Roadside Settlement House; he was active in American Red Cross fund drives; and in 1950 he was appointed to the Executive Committee of the Bureau of Municipal Research of Des Moines, an organization to which he belonged for many years.

In the field of religious activities, Riley was appointed in 1944 to the Advisory Committee of the Catholic Student Center at The University of Iowa, a position in which he was quite active until his death in 1956; he was a frequent speaker at Catholic social functions; and he served on the Board of Trustees at The University of Iowa School of Religion.

In addition to following a vast number of civic and religious pursuits, Riley also became extremely active in the state and national bar associations. In capsule form his bar association activities between 1940 and 1950 were these. For the American Bar Association Riley served on the Public Relations Committee, the Resolutions Committee, and the Committee on Improving the Administration of Justice. For the Iowa State Bar Association he served on the Committee on Unauthorized Practice and on the Law Reform Committee; and he also served as chairman of the War Readjustment Committee, chairman of the Committee on Public Relations, chairman of the Committee to Study Divorce Problems, and chairman of the Committee on Ways, Means, 
Scope, and Correlation. In addition, William Riley was elected vicepresident of the Iowa State Bar Association in 1948 and Association president the following year. Thus, the Riley collection contains a significant quantity of material dealing with various important civic, religious, and bar association activities of the 1940s. Students of Iowa history, politics, law, and public affairs should find in these papers a most fruitful reservoir of information for meaningful research projects.

\section{RILEY THE FEDERAL DISTRICT JUDGE}

On December 28, 1950, William Riley took the oath of office as Iowa Southern District Federal Judge after having been appointed to that position by President Truman several weeks previously. Almost half of the Riley collection consists of materials dealing with the varied aspects of the Judge's six-year judicial tenure. These judicial papers consist primarily of letters between Riley and other federal district judges within the U.S. Eighth Circuit, of which Iowa is a part; and they contain some extremely keen insights into the function, impact, and internal dynamics of the federal court system. As a student of the judicial process, this writer was able to divide Riley's judicial papers into seven different categories, each of which has its own theoretical significance.

First are the problems faced by a newly-appointed federal trial judge as he attempts to learn the various duties and procedures which are suddenly thrust upon him after taking the judicial oath. This note from Riley to Iowa Northern District Federal Judge Henry Graven is typical:

This morning I held my first court session. . . .

It has occurred to me that you may be willing to make some very helpful suggestions drawn on [your] own experience that might help me along this trail that I am trying to follow. I refer even to techniques that you will have adopted in the impanelling of your grand and petit jury and in the selection of your jurors in civil and criminal cases or to a system of notes which you have found effective. . . . I shall appreciate whatever you may suggest. ${ }^{2}$

A second category consists of material relating to Judge Riley's conception of the judicial role, that is, of what he expected of himself and of what he thought others expected of him as a federal district judge. It should be noted that social and political scientists have been making increasing use of role analysis as a research method, and the Riley papers serve as a basis for extending this method to the study of judicial behavior.

William F. Riley to Henry Graven, January 5, 1951. 
Another category of information depicts the role of the Eighth Circuit Court of Appeals and its chief judge in relation to the various district judges within the circuit. In this same category there is some evidence indicating the criteria by which appellate judges are evaluated by federal district judges. For example, the following excerpt from a Riley letter to newly-appointed Appellate Judge Charles Vogel illustrates how trial judges feel about the need for appellate judges to have had prior trial court experience:

It is therefore a great pleasure to write this letter, and to tell you how happy I am that you have received this appointment. It is not only personally gratifying on your account. but it is gratifying to me, as I know it will be to other District Judges, that a nisi prius Judge is going to the Appellate Court. There will be a sympathetic understanding of the problems of the trial Judge in trying to administer justice, that no one can quite appreciate until he has himself shared the experience. Unhappily, there is evidence that a court composed largely of Advocates does not have as judicial an approach as might be desired. ${ }^{3}$

Category four contains data which demonstrate the impact of the Eighth Federal Circuit upon the administration of justice within the circuit. Evidence in the Riley papers suggests that the Eighth Circuit tends to be a system unto itself, having its own traditions and idiosyncrasies, socializing its own members, and possessing, to a limited degree, its own judicial philosophy. It is significant that 97 per cent of Riley's correspondence was conducted within his own circuit; only 3 per cent of his letters were written to judges outside the Eighth Circuit.

A fifth category provides insight into the relationship between the Iowa district judges and various national executive and legislative officials, such as the President, the Attorney General and his staff, the directors of the Administrative Office of U.S. Courts, Iowa Senators Guy Gillette and Bourke Hickenlooper, and Iowa Congressman Karl LeCompte. For example, there is evidence to demonstrate the influence possessed by a U.S. senator in influencing appointments to the district court staff.

Category six contains evidence that local needs and conditions often influence the administration of federal justice, and that as a consequence the administration of federal justice varies markedly from district to district and from state to state.

A final category of data illustrates the large amount of interaction between Judge Riley and the Iowa judicial, political, and social systems. These data suggest that the U.S. district judge may exert as much

3 William F. Riley to Charles Vogel, September 2, 1954. 
influence on the purely state and local culture as he does on the administration of federal justice.

In sum, the Riley judicial papers contain a wealth of information for any student of law or of the judicial process who has a particular interest in the function, impact, and internal dynamics of the federal judicial hierarchy. 